\section{Birds of the}

\section{Cut Arm Creek}

BY LAD. MARTINOVSKY GERALD Sask.

My farm is only a short distance from this creek, well sheltered with lots of planted trees of many varieties including evergreens.

The birds have not gone hungry this winter as an abundance of dried fruit, such as chokecherry, cranberry, hawthorn, rose hips, snowberries and maple seed, remained on the trees.

Often we see dozens of Pine Grosbeaks and Bohemian Waxwings through the kitchen window, feeding on the fruit of a big yellow siberian Crab that was covered with fruit last fall and left for the birds.

Birds are plentiful in the summer around our home because there are so many nooks where they can start hou sekeeping. I have a bird bath for them and earth-worms are abundant in the garden. The contentment of the birds is verified by their continual music in the early morning. It is beautiful.

Hummingbirds are common as there are a profusion of garden flowers in bloom from early spring till late fall.

Magpies are becoming more prevalent in this district than in the past and Blue Jays are common, The Canada Jays, one time plentiful, have completely disappeared.

On October 29, while I was combining at night, a White Owl arrived and sat on the granary. Two Golden Eagles circled overhead, on their way south, November 14th. Owls and hawks are not common in this district as there are very few rabbits and gophers for them to feed on.

By the middle of February the unsual winter birds were very plentiful at Nipawin. About 75 Bohemian Waxwings stripped just about all the pin cherries from the trees near Maurice Street's kitchen window. Flocks of from ten to twenty Ravens were not unusual. Billy Matthews banded some 200 Redpolls during the week ending February 10th.

\section{Swallows}

\section{By Clarissa Stewart, Fairy Hill}

Heigh-ho ! To be a swallow To swoop and swerve and sail Across the misty fallow

Or floating on the gale

In poetry of graceful motion

Lighter than waves of sunlit ocean.

With nest high on the rafter

Ringed round with bright-eyed heads Chuckling with family laughter

On lovely far homesteads,

Or on the telephone's high wire

Conversing like a cheerful choir.

On swift wing shining bluely, With snowy spots a row, And breast of soft tan, truly No sweeter bird I know :

I wait their coming in the spring And sigh in fall when they take wing.

\section{Believe it or Not}

The Groundhog may or may not have gone back for another nap on February 2, but there are other animals and birds that brave the rigors of our prairie winter, come what may.

There was the Robin who in company with a crow stuck it out through the entire winter, near T.H Mc Lellan's home at Arcola. It was there too, that three Starlings wintered in a hole in a sheaf stack. At least one song snarrow stayed for Christmas, at any rate it sang a song on a willow bush, near Grenfell, on December 11 Mrs Bilsbury will vouch for that. On January 26 she saw a White-crowned Sparrow keeping company with four house sparrows. A week later it was still enjoying the sub-zero weather.

\section{Most Northern Subscriber}

The BLUE JAY'S most northern subscriber is Mrs. A. W. Mudiman, who lives at Whitehorse. Mrs. Mudiman has made an extensive study of the birds of the Yukon Territories. We hope to have a report from her soon. 